\title{
References
}

Armour-Brown, A., Tukiainen, T., Wallin, B., Bradshaw, C. \& Emeleus, C. H. 1983: Uranium exploration in South Greenland. Rapp. Grønlands geol. Unders. 115, 68-75.

Tukiainen, T., Bradshaw, C. \& Emeleus, C. H. 1984: Geological and radiometric mapping of the Motzfeldt Centre of the Igaliko Complex, South Greenland. Rapp. Grønlands geol. Unders. 120, 78-83.

Department of Geological Sciences, University of Durham, Science Laboratories, South Road, Durham, U.K.

\section{New observations on the easternmost extension of the Gardar supracrustals (Eriksfjord Formation), South Greenland}

\author{
Lotte Melchior Larsen and Tapani Tukiainen
}

During the 1984 field work in the Motzfeldt Centre of the Igaliko Complex, some of the remnants of the supracrustal rocks of the Eriksfjord Formation were investigated. These occur at several localities bordering the centre, and are also found as inclusions (roof rafts) of variable size within the syenites of the centre. These supracrustal rocks form the easternmost extension of the sandstones and lavas of the Eriksfjord Formation, the major part of which is found on the Narssaq peninsula to the west.

Some of the easterly remnants were described by Emeleus \& Harry (1970) who noted the occurrence of sandstone and volcanic breccia, agglomerate and lava flows and described two small agglomerate-filled volcanic plugs. Our observations extend those of Emeleus \& Harry (1970).

\section{New observations}

South-east Motzfeldt Centre. The southern part of the syenites in the area contains a roof raft of supracrustal rocks a little more than $1 \times 0.5 \mathrm{~km}$. The supracrustals occur at altitudes of 880 to 1490 metres with massive volcanics above $1160 \mathrm{~m}$. At two levels syenite sheets 20 and $140 \mathrm{~m}$ wide have intruded along the bedding planes. The raft is thus in an early state of disintegration. The supracrustals dip $10-20^{\circ}$ northwards, and the succession consists of about $40 \mathrm{~m}$ of volcanic rocks succeeded by around $100 \mathrm{~m}$ of grey and reddish quartzitic sandstone, followed by a massive sequence of about $400 \mathrm{~m}$ of volcanic rocks. The volcanics comprise thick flows of reddish brown trachytes, both feldsparphyric and aphyric, and flow-banded feldsparphyric felsic lavas. A thin unit with ignimbrite structure was also found. The sequence contains one basalt flow or sill about $30 \mathrm{~m}$ thick. The sandstones are cut in two places by irregular dyke-like bodies of dense, dark grey ultramafic rocks one of which is pillowed.

North of the major E-W sinistral fault in the south-east Motzfeldt Centre, small scattered supracrustal remnants occur in an area of about $1 \times 2 \mathrm{~km}$ at an altitude of about $1700 \mathrm{~m}$. The 
remnants vary in size from less than $10 \mathrm{~m}^{2}$ to more than $100 \times 100 \mathrm{~m}$. They lie within a heavily altered and mineralised microsyenite but appear to be virtually unaffected by the alteration and mineralisation. The supracrustal rocks comprise a variety of mafic/ultramafic volcanics and subordinate sandstone and conglomerate. The volcanics are mainly coarse agglomerates with a carbonate-rich matrix. The fragments are fine grained to aphanitic rocks with a high content of carbonate and phlogopite. Some rocks have remains of plagioclase phenocrysts showing that they are carbonated basaltic to intermediate lavas.

Small irregular intrusives of ultramafic rocks with sandstone xenoliths also occur in the Julianehåb Granite adjacent to the centre.

North-east Motzfeldt Centre. The supracrustals here consist of about $150 \mathrm{~m}$ of sandstone on top of which follows a mixed sequence of volcanic rocks and sandstone. In contrast to Emeleus \& Harry (1970) we found the base of the Eriksfjord Formation between 1200 and $1250 \mathrm{~m}$ altitude, and the total exposed thickness of the formation here is approximately 300 metres. The bulk of the formation consists of quartzitic sandstone with sporadic intercalations of grit and shaly sandstone. The lowermost layer of volcanics was found at an altitude of about 1380 $\mathrm{m}$. There are three prominent layers of volcanics in the sequence at altitudes of 1380, 1420 and $1500 \mathrm{~m}$ respectively. The thickness of these layers varies from $10 \mathrm{~m}$ to $20 \mathrm{~m}$. The volcanics consist of basaltic lavas, tuff and agglomerates with subordinate trachyte.

Central Motzfeldt Centre. In the Motzfeldt $§ \varnothing$ Formation syenites between the glaciers Qôrqup sermia and Sermia avanardleq a body of volcanics approximately $1.5 \times 0.5 \mathrm{~km}$ was found this year (Tukiainen, this report, fig. 19). The volcanics are reddish brown and greyish trachytes, either feldsparphyric or aphyric and vesicular. A thick reddish brown, highly porphyritic, rhomb-porphyry lava of probable trachyandesitic composition is also present. In the Flinks Dal Formation syenites, $2 \mathrm{~km}$ to the south, small scattered remnants of a greyish feldsparphyric trachyte were also found. These remnants are similar in character to the large raft of trachytic lavas in the middle of the centre described by Emeleus \& Harry (1970).

\section{Implications}

It is a general feature of the remnants of the Eriksfjord Formation around the Motzfeldt Centre that they consist of a lower sequence of sandstone, resting on the basement, and an upper sequence of mixed sandstone and volcanic rocks rich in agglomerates. The lower sequence can be correlated with the Mâjût Sandstone Member of Poulsen (1964) which comprises the section of sandstone between the underlying Julianehåb Granite and the first manifestation of volcanism. The upper sequence can be correlated with the succeeding Mussartût Member (Poulsen, 1964) which is a mixed sequence of tuffs, volcanic breccias, lavas, sills, sandstone and conglomerate.

The Mussartût Member is present over the whole extension of the Eriksfjord Formation, and a consistent feature of this member is the occurrence of ultramafic and carbonatitic rocks. These, however, seem much more predominant in the eastern than in the western areas. While only a few thin ultramafic lava flows have been recorded from the western areas (Narssaq and Nunasarnaussaq) by Stewart (1964), the eastern areas include the relatively large occurrences of carbonatites and ultramafic volcanics at Qagssiarssuk (Stewart, 1970). We have found that such rocks are common in the Motzfeldt area. 
A notable contrast between the western and eastern parts of the lower Eriksfjord Formation is seen in the relative amounts of basic and evolved lavas. In the west, the volcanics in the lower part of the Eriksfjord Formation are almost exclusively basaltic (Stewart, 1964), whereas the eastern remnants around, and within, the Motzfeldt Centre have an overwhelming preponderance of differentiated lavas, mostly trachytes, while basalts apparently constitute less than 10 per cent of the volcanics. The only other sequence with differentiated lavas is the Ilimaussaq Volcanic Member from the upper westernmost part of the Eriksfjord Formation around the Ilimaussaq intrusion. The trachytic and trachyandesitic lavas make up about one third of the volcanics in this member (Larsen, 1977). There is an apparent correlation between the occurrence of differentiated lavas and later syenitic intrusive centres. Even though the lavas and syenites in one place are not directly related petrogenetically they may owe their origin to the same structures in the deep crust or at the crust-mantle boundary, which facilitated the development of differentiated magmas. Such structures could be cupolas on larger magma pools.

\section{References}

Emeleus, C. H. \& Harry, W. T. 1970: The Igaliko nepheline syenite complex. General description. Bull. Grønlands geol. Unders. 85 (also Meddr Grønland 186,3), 116 pp.

Larsen, J. G. 1977: Petrology of the late lavas of the Eriksfjord Formation, Gardar Province, South Greenland. Bull. Grønlands geol. Unders. 125, $31 \mathrm{pp}$.

Poulsen, V. 1964: The sandstones of the Precambrian Eriksfjord Formation in South Greenland. Rapp. Grønlands geol. Unders. 2, $16 \mathrm{pp}$.

Stewart, J. W. 1964: The earlier Gardar igneous rocks of the flimaussaq area, South Greenland. Unpubl. Ph.D. thesis, Univ. Durham, England.

Stewart, J. W. 1970: Precambrian alkaline-ultramafic/carbonatite volcanism at Qagssiarssuk, South Greenland. Bull. Grønlands geol. Unders. 84 (also Meddr Grønland 186,4) 70 pp.

\section{Ketilidian uranium mineral occurrences in South Greenland}

\section{Ashlyn Armour-Brown and Bjarne Wallin}

The Sydex project is financed by the Ministry of Energy's Research Programme 1984 in order to evaluate the uranium mineral occurrences found during the earlier reconnaissance project, Syduran.

The main objectives of the field season were:

(1) to map and sample in detail the uranium occurrence at Igdlorssuit (fig. 20) in the Migmatite Complex which was found in 1982 (Armour-Brown et al., 1984), so as to evaluate its economic potential and place it in its geological setting,

(2) to locate the source of a high gamma-spectrometer anomaly on the nunatak north of Nordre Sermilik in the Granite Zone, and to map the surrounding geology. 